\title{
An Economic Analysis of International Capital Flow
}

\author{
Duo Li \\ School of Economics, Jinan University, Guangzhou, China \\ Email: LDzcheng@126.com
}

How to cite this paper: Li, D. (2018) An Economic Analysis of International Capital Flow. American Journal of Industrial and Business Management, 8, 404-416. https://doi.org/10.4236/ajibm.2018.82026

Received: January 26, 2018

Accepted: February 24, 2018

Published: February 27, 2018

Copyright (C) 2018 by author and Scientific Research Publishing Inc. This work is licensed under the Creative Commons Attribution International License (CC BY 4.0).

http://creativecommons.org/licenses/by/4.0/

\begin{abstract}
The flows of international capital are determined by a variety of factors. Among them, there are both realistic and historical factors, both economic and non-economic factors. This paper mainly explores the causes of international capital flows from economic factors. The first part mainly discusses the related concepts and classifications of international capital flows. The second part presents the main findings at home and abroad. The third part summarizes the main influencing factors of international capital flows based on the theoretical results. Finally, taking the reality of China's direct capital investment as an example, the paper empirically analyzes the factors affecting international capital flows.
\end{abstract}

\section{Keywords}

International Capital Flows, Motivation, Influencing Factors, FDI

\section{The Concepts and Classifications of International Capital Flows}

\subsection{The Concepts of International Capital Flows}

International capital flows mainly refer to the paid transfer of the right of the use of monetary capital between countries [1]. International capital flows are traded primarily through international and domestic financial markets, such as borrowing money or investing. As for the classification of international capital flows, according to the length of using capital, they are classified into long-term capital flows and short-term capital flows.

\subsection{The Classification of International Capital Flows}

According to the different ways of transfer, long-term capital flows are divided 
into direct investment, securities investment and international credit. The most prominent feature of long-term capital flows is the long duration of funds and their large numbers, which has a great impact on long-term economic stability and sustainable development. For capital-exporting countries, long-term capital flows can increase the marginal benefit of capital; help to occupy the world market, promote the export of goods and services; help to overcome barriers to trade protection; and promote international status. For capital-importing countries, long-term capital flows can alleviate the difficulties of capital shortages; raise the level of industrialization; expand the quantity of product export; improve the international competitiveness of products; and increase employment opportunities in the emerging industrial and tertiary sectors.

According to the different reasons or characteristics of the capital flows, short-term capital flows are divided into trade settlement and short-term financing, bank capital flows, hedge capital flows and speculative capital flows. The main characteristics of short-term capital flows are the short duration of use and good liquidity. The impacts of short-term capital flows on the domestic economy are mainly reflected in the balance of payments, exchange rate and monetary policy. The short-term speculative capital flows mainly affect the process of international economic and financial integration, the operation of international financial market and the allocation of funds among countries.

This paper presents the main findings, main contributions and limitations of this research.

\section{The Main Findings at Home and Abroad}

\subsection{Foreign Findings}

By studying the development of international capital flows theories, we can conclude that there are four basic theories about international capital flows motivations, such as Flow theory, Portfolio Theory, Monetary Analysis Theory and Transaction Cost Theory.

\subsubsection{Flow Theory}

The flow theory of international capital flows focuses on exploring the relationship between capital flows and the level of interest rate. According to the theory, interest rate is the decisive factor of international capital flows, and the differences of interest rate causes capital flows. The growth of foreign interest rate increases the outflows of domestic capital to foreign countries, which will continue if the foreign interest rate keeps a high level relative to domestic interest rate. On the contrary, the growth of domestic interest rate would lead to inflows of foreign or reduce domestic capital outflows. Meade proposed a model to explain the flow theory: [2]

Trade balance: $T=T\left[Y^{-}, e / P^{+}\right]$

Among them, the trade balance is expressed by $T$; the total output is expressed by $Y$; the exchange rate is expressed by $e$; the price level is expressed by $p$. 
Capital flow: $F=F\left(i^{+}, i^{*_{-}}\right)$

Among them, the capital is expressed by $F$; the domestic interest is expressed by $i$; the foreign interest is expressed by $i$.

Balance of payments: $\Delta R=T+F=T\left[Y^{-}, e / P^{+}\right]+F\left(i^{+}, i^{*_{-}}\right)$

In the Meade model, because the rise of domestic interest rates will attract foreign capital inflows, when output and price levels are given, the rise of domestic interest rates improves the balance of payments. Within the framework of flow theory, Mundell and Fleming further explained that international capital flows are determined by interest rates. Mundell (1960) believed that relatively high domestic interest rates will increase net capital inflows or reduce net capital outflows; Fleming (1962) further points out that international capital flows are more sensitive to interest rates under a floating exchange rate than under a fixed exchange rate system. The study of Mundell (1963) held that interest rates and exchange rates are the main factors affecting the international capital flows.

\subsubsection{Portfolio Theory}

On the basis of the portfolio theory, Branson (1968) analyzed international capital flows and believed that short-term capital flows are determined by imports, exports, interest rates and exchange rates, while long-term capital flows are determined by domestic income, interest rates and foreign interest rates. $\mathrm{He}$ also took these factors into the Markowitz Tobin model, and concluded that the ratio of foreign assets to a given wealth is a function of domestic interest rate, foreign interest rate, risk and the stock of wealth, i.e.:

$$
F / W=f\left(i-i^{*}, E, W\right)
$$

Among them, the foreign asset is expressed by $F$; the stock of wealth is expressed by $W$; the domestic interest is expressed by $i$; the foreign interest is expressed by $I^{*}$; the risk is expressed by $E$.

Under the model, investors can allocate the proportion of assets according to the balance between income and risk. When the market appears unbalanced between supply and demand, the actual proportion of assets is not matched with the willing portfolio proportion, so the existing portfolio can be adjusted. The flows of assets depend on the rate of return, risk forecast and investor's wealth.

\subsubsection{Monetary Analysis Theory}

Monetary Analysis Theory holds that monetary policy determines international capital flows, which is essentially a monetary phenomenon and determined by domestic monetary policies and changes in the reserves. The internal and external flows of capital constitute the total state of the balance of payments. Harry (1972) gave a monetary analysis model of international capital flows: [3]

Money demand function: $H_{d}=H\left(P^{+}, Y^{+}, i^{-}\right)$

Money supply function: $H_{\mathrm{s}}=H(1 / \varphi)(R+D)$

Among them, the price level is expressed by $P$; the total output is expressed by $Y$; the interest rate is expressed by $i$; the domestic credit is expressed by $D$; the international reserves is expressed by $R$; the statutory reserve ratio is expressed 
by $\varphi$.

Balance of supply and demand of money: $R+D=\varphi H(P, Y, i)$

Balance of income and expenditure of balance:

$$
\mathrm{d} R=H \mathrm{~d} \varphi+\varphi H_{1} \mathrm{~d} P+\varphi H_{2} \mathrm{~d} Y+\varphi H_{3} \mathrm{~d} i-\mathrm{d} D
$$

The theory of monetary analysis holds that the increasing of total output or the rise of price level will increase the demand for money and improve the balance of payments; However higher interest rates will reduce monetary demand and thus worsen the balance of payments. It can be found that this conclusion contradicts the flow model. But this contradiction is explained in the general equilibrium model of Frankel and Honeywell (1980), which holds that the short-term flows of international capital depend on the level of interest rate. And the long-term flows of international capital are influenced by money stock adjustment and domestic credit policy.

\subsubsection{Transaction Cost Theory}

In 1990s, the trend of globalization of financial market was increasingly obvious, and international capital flows also presented some new characteristics, such as large scale, multi-direction and securitisation. It was difficult for the existing theory to explain this problem. Kim (1999) puts forward a transaction cost model to explain the globalization of capital flows. The expression of the model is:

$$
\mathrm{d} Y_{t} / \mathrm{d} I^{*}=r^{*}\left(1-C^{*}\right)-r(1-C)
$$

Among them, the sum of investment returns at home and abroad is expressed by $Y$; the domestic investment is expressed by $I$; the domestic interest rate is expressed by $i$; the foreign interest rates is expressed by $I^{*}$; the domestic transaction cost is expressed by $c$, the foreign transaction cost is expressed by $c^{\star}$.

Transaction cost theory shows that transaction cost is an important factor affecting international capital flows, including search and information costs, negotiation and decision-making costs, and implementation and monitoring costs. Compared with the flow model, the transaction cost model holds that the international capital flows are not only influenced by the interest rate difference at home and abroad, but also restricted by the transaction cost of domestic and foreign investment.

\subsubsection{Main Contributions}

The four classical theories reveal various factors that affect the transnational capital flows from different sides and different perspectives. The flow theory explains that differences in interest rates can lead to international capital flows; The portfolio theory further recognizes that besides interest, the ability of investors and the credit of capital-importing countries are also important factors that influence the transnational capital flows; The monetary analysis theory examines the flows of international capital from the perspective of monetary policy and domestic credit; The transaction cost theory uses the theory of transaction cost in economy to explore the important role of transaction cost in international capital flows. 


\subsection{Existing Domestic Findings}

The analyses of capital flows in domestic mainly focus on the capital flight of China and the influencing factors of FDI, while the research on the causes of international capital flows is relatively limited. The main results are the following:

Wang Guosong et al. (2006) took CF1 (the sum of the increase in official reserves and the difference between import and export) and CF2 (the sum of the net investment income, as well as the difference between import and export and the increase in official reserves) as explanatory variables. Respectively, price levels, interest rate spread and nominal exchange rate expectations are used as explanatory variables. The empirical results during the entire sample of 1982-2004 show that the main factor affecting the flows of capital in China is the RMB exchange rate expectation, and none of the other factors passed the test. However the test of 1982-1993 years is not ideal, and the results of the test in 1994-2004 are ideal except for the interest rate spread [4].

Wang Qi's (2006) study measured capital flows in China by merging missing accounts and the net error in capital and financial accounts. He choose the difference of Interest rates, the exchange rate and prices between China and the United States, at the same time, he introduced two new variables: trade openness and exchange rate system reform, He explained the capital flows from 1985 to 2003 in China, and the test results showed that the exchange rate, policy variables and trade openness had strong explanation to the Chinese capital flow ability, however the effect of interest rate spreads was very weak, the price difference is not passed the statistical test [5].

To sum up, the studies of Chinese researchers on the motivations of Chinese capital flows are all conducted from the interest rate, exchange rate, trade openness and exchange rate system. However, due to the different ways of selecting variables, the empirical results are also different. Even significant variables in a scholar's study fail to pass tests in other scholars' studies.

\section{International Capital Flows Factors}

Through the development of international capital flows theories at home and abroad, the internal mechanism of influencing international capital flows has always been the hot soil for scholars to study, and it is also the foundation for the development of international capital flow theory. Only by learning the specific causes of capital flows in the world can we see the essence of capital flows and make effective use and control of them. Although we are unable to make clear all the causes of international capital flows, we try to found the most fundamental and representative points that affect international capital flows, and expect to have a general understanding about international capital flows.

The deepest purpose of international capital flows is to obtain higher returns. Therefore, international capital flow is essentially a profit-seeking behavior, so the interest rate determines the flows of international capital and all can change the expected return of the factors can affect the international capital flows. In 
this paper we discuss the most important several factors.

\subsection{The Differences in Economic Development and Development Capacity of Each Country}

There is a certain link between economic development and international capital flows. It is generally believed that the positive effect of international capital flows is to promote the economic development of the country which capital flows into, to complement each other's international resources and to enhance the welfare of all countries of all countries in the world, so as to bring the international economic development into a virtuous circle. The virtuous circle of the international economy in turn promotes international capital flows, and obviously enlarges and increases its scale and speed. The continuous improvement of the economic development level will promotes the international capital flows. It can be said that they have a causal relationship with each other. In addition to the practical ability of national economic development, the potential capacity of national economic development can also affect the future trend of international capital flows. Because of the difference of national economic development level, international capital flow is not only for the purpose of configuration physical resources, but also for the income from international capital investment or speculative, so that the scale of international capital flow is bigger and bigger, and the speed is quicker and quicker.

\subsection{The Price Difference between Countries}

The magnitude of the rising price level is the primary indicator of the stability of a country's economy, and the stable investment environment in the host country is a favorable factor in attracting capital inflows. Because domestic inflation will not only lead to rise the price of production factors, improve the production cost, but also may lead to currency devaluation, cause the domestic currency fluctuations, which are all the risk factors that affect foreign capital inflows. From another point of view, the rise of price in our country will result in the reduction of real interest rates between home and abroad. As a result, the difference between the return on investment at home and abroad has been reduced. Therefore, if the difference between domestic prices and foreign prices increases, inflow of capital will reduces, outflow of capital will increases.

\subsection{Interest Rate Spread between Countries}

As discussed earlier, in no way is the process of economic development in all countries parallel and same, so in the same period, the economic policies of various countries are also different. Starting from reality, all countries formulate their own macroeconomic policies, fiscal policies and monetary policies. Due to the different degree of tightness of the monetary policy chosen by each country in the same period, the interest rate levels formed through the monetary policy transmission mechanism are also different. The existence of country-level dif- 
ferences in interest rates is an objective fact, and interest rates are the prices of funds. Since they are different in different countries, international capital flows have become inevitable. Assuming other factors remain unchanged, countries with low interest rates will have international capital outflows and countries with high interest rates will have international capital inflows. It can be said that country-level spreads will lead to international capital flows. The difference of interest rates will affect the manner, scale and speed of capital flows. Compared with the direct investment method, the loans of international commercial banks have a strong sensitivity to the spread and its extent. The securities investment also has certain sensitivity to the spread and its extent.

\subsection{The Changes Onex Change Rate System and Exchange Rate in Various Countries}

The changes on exchange rate system and exchange rates in various countries have a certain impact on international capital flows. Exchange rate changes adjust the balance of payments through changes in the relative price of money. There are two adjustment mechanisms. The first adjustment mechanism is that exchange rate changes can realize the country's balance of payments by changing commodity prices and changing import and export trading conditions. The second adjustment mechanism is that exchange rate changes can promote currency conversion by private investors. The implementation of a floating exchange rate system will further stimulate the flow of international capital flows, especially private capital flows. China's rate of experience has gone from a fixed exchange rate to a floating exchange rate. The rate of exchange rate changes is from small to large, and the widening of the rate of exchange rate changes has greatly promoted the flow of international capital.

\subsection{Capital Controls and the Degree of Capital Liberalization}

For a country's economy, capital is of the utmost importance, and countries all over the world also place great emphasis on capital and capital regulation. Theoretically, if there are a surplus of domestic savings and no good investment projects in the country, then the country will encourage the cross-border export of domestic capital. Therefore, these countries will formulate relatively loose capital regulation policy and encourage capital liberalization. This implementation of capital liberalization will promote the flow of international capital and will have a significant impact on the way, structure and scale of international capital flows. If a country has insufficient domestic savings, and faces the pressure of accelerating its economic development as well as its domestic investment is insufficient, Then the country will encourage the introduction of foreign capital, import capital from abroad, reduce the output of domestic capital relatively and reduce the capital flight, which will all inevitably affect the way, structure and quantity of international capital flows. Therefore, both the implementation of capital liberalization and the implementation of capital regulation will even- 
tually have an impact on international capital flows.

\section{An Empirical Analysis of International Capital Flows-Data Analysis Based on China's FDI in 1989-2013}

According to the analysis above, we know that the capital flow in our country is mainly affected by the difference of interest rates, price, exchange rate, the domestic economic development, capital regulation and capital liberalization. Due to the difficulty of data collection, especially data in foreign countries, the paper only analyzes the main factors influencing FDI, such as interest rate, inflation rate, exchange rate and domestic economic development. As for the impact of capital regulation and capital liberalization, they have essentially been reflected in factors such as exchange rates, interest rates and prices. If we add these two factors to the regression analysis, we will have the problem of multicollinearity instead. And the sources of this paper are all Wind network. Among them, we selected FDI as an indicator of international capital flows, GDP as an indicator of the degree of domestic economic development, the exchange rate of RMB against the U.S. dollar as an indicator of exchange rate, the interest rate of deposits on delivery as an indicator of domestic interest rates, and CPI as the measure of domestic price indicator. The time range was from 1988 to 2013.

\subsection{Variable Selection}

\subsubsection{Explanatory Variables-Direct Investment (FDI)}

Direct investment (FDI) is a very important way in the international capital flows. All countries are very concerned about their scale and trend. Compared with short-term international capital flows, investment international capital flows in the form of FDI are more stable. It is desirable that we choose FDI as the research object. In this paper, we select the annual data from 1989 to 2013 to empirical analysis. As shown in Figure 1, China's direct investment increased year by year.

\subsubsection{Explain the Variables}

As the main factors affecting international capital flows include the level of economic development, prices, interest spreads and exchange rates, here, we select the variables as follows:

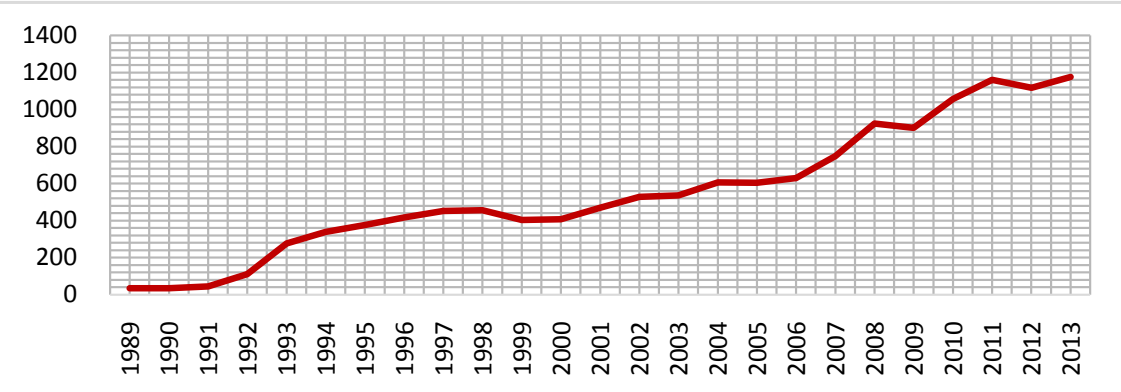

Figure 1. The Trend of China's FDI. 
1) GDP: Since the vast majority of China's net capital flows are provided by FDI inflows, among the factors that influence the FDI inflows, the stability of a country's macroeconomy is attractive. Therefore, we predict the net GDP-capital inflow should have a positive correlation with FDI inflows. As shown in Figure 2, China's GDP also shows an upward trend over time.

2) Interest rate (LLV): Due to the difficulty of obtaining foreign data, this paper only considers the domestic interest rate and does not compare with foreign interest rates. We use the current deposit interest rate as an indicator. As shown in Figure 3, China's interest rate in 1993-1999 increased more obviously, and subsequently fluctuated litter.

3) Consumer Price Index (CPI): In order to reflect the comprehensive price level of a country, we use the CPI here to reflect the price index which is the primary indicator of the stability of a country's economy. Because the domestic inflation will lead to the rise of production price, increase the production cost, and at the same time it may lead to currency devaluation and cause the fluctuation of domestic exchange rate, which will all become the risk factors affecting the foreign capital flows. Therefore, it is reasonable to predict the inverse

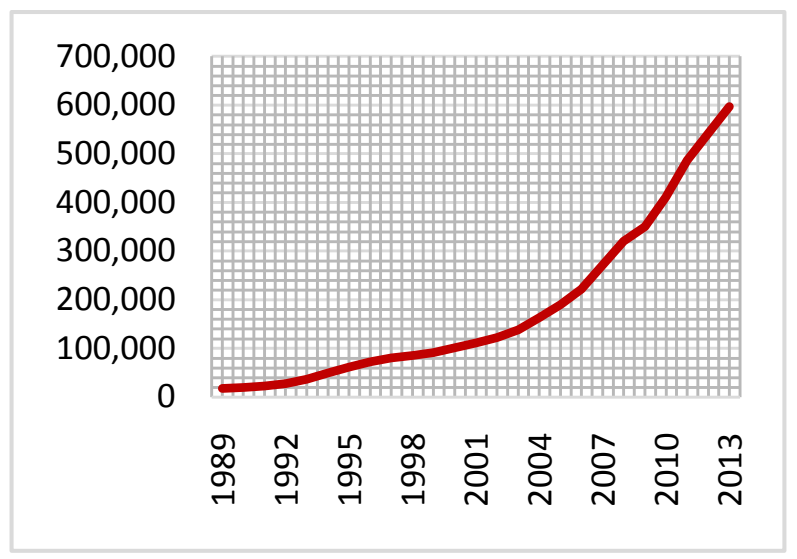

Figure 2. The Trend of China's GDP.

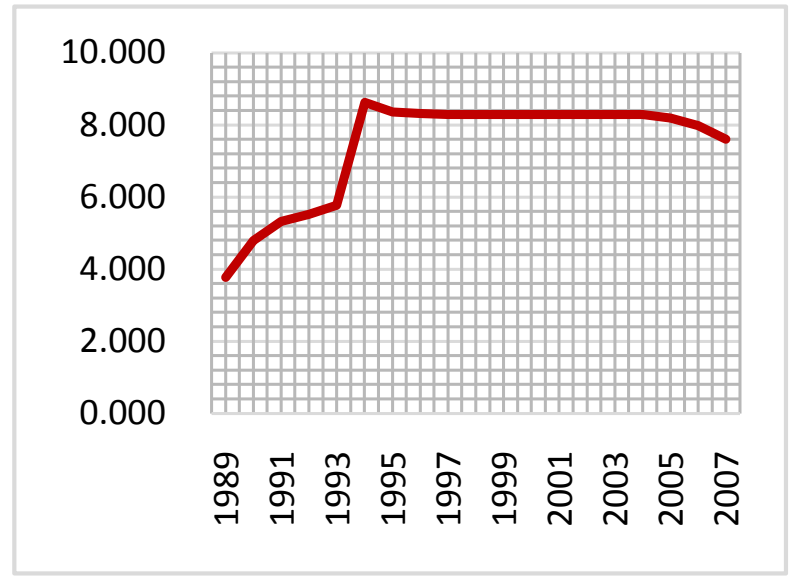

Figure 3. The Trend of China's interest rate. 
relationship between FDI and CPI. As shown in Figure 4, China's CPI also shows an upward trend over time.

4) $\mathrm{RMB}$ exchange rate (FER): in Figure 5, we use the nominal exchange rate between RMB and dollar (FER) as the explanatory variable. The relationship between exchange rate change and China capital flows can be discussed from two aspects. on the one hand, a country's currency appreciation, means its overseas purchasing power increasing and a slowdown in the domestic purchasing power for foreign investment, which will lead to increase investment aboard and curb inflows from foreign countries; On the other hand, a country's currency appreciation can fully display its stable investment environment, which will attract a large number of foreign capital inflows, so the effect of exchange rate on China's capital inflows behind has yet to be tested.

\subsection{Setting the Model}

Here, we chose the least square method as the measurement method to study

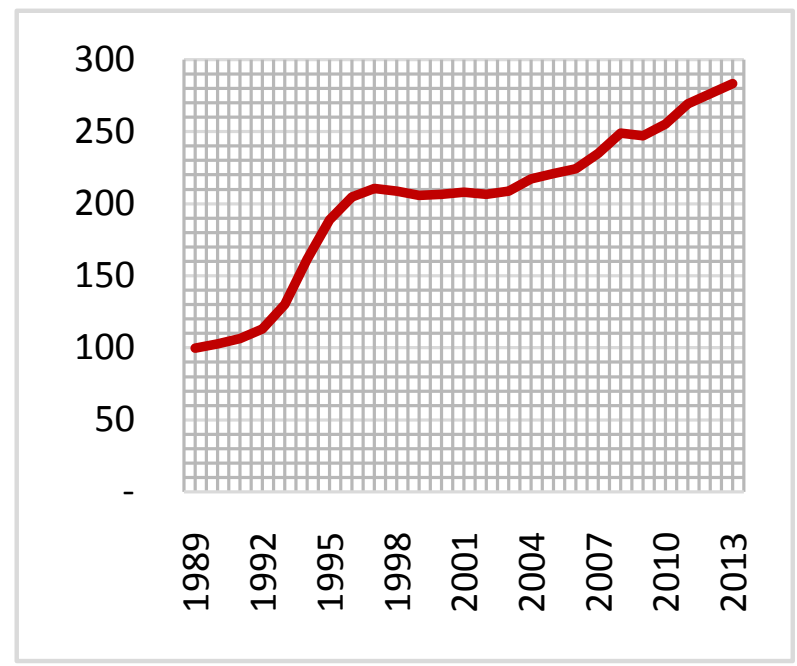

Figure 4. The Trend of China's CPI.

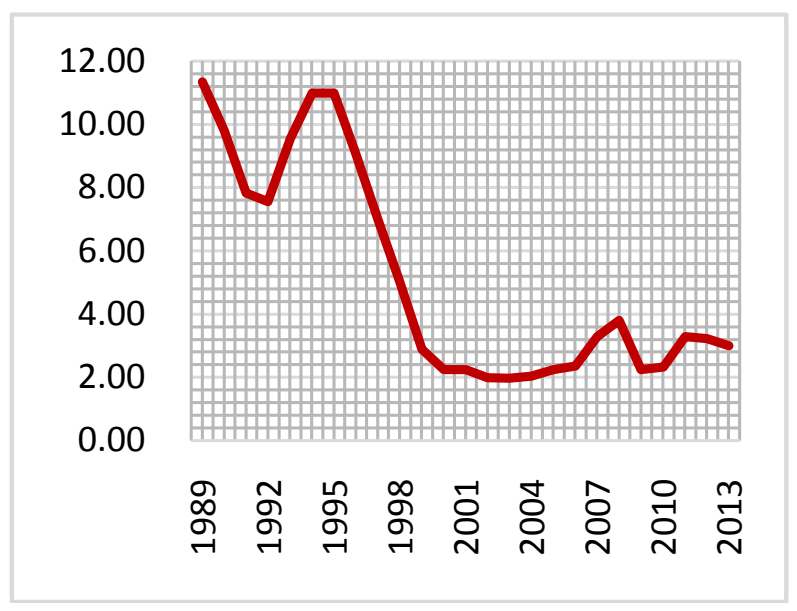

Figure 5. The Trend of RMB exchange rate. 
the influencing factors of China's international capital flows. We preliminary establish measurement model as follows:

$$
\mathrm{FDI}=\mathrm{C}+\beta_{1} \mathrm{GDP}+\beta_{2} \mathrm{CPI}+\beta_{3} \mathrm{LLV}+\beta_{4} \mathrm{HLV}
$$

\subsection{Experiment Steps}

1) First of all, we can calculate the correlation coefficients between variables. The specific data is as follows.

From Table 1, obviously there is a certain correlation between dependent variable and independent variables, especially the correlation between FDI and CPI, as well as GDP are both up to more than $90 \%$, so multiple regression analysis can be used to analyze the correlation between them.

2) We made OLS regression by using E Views software, and the test results were shown in Table 2.

From the above equation results and other data, we can see that the adjusted R2 was 0.979 which meant equation fitting better and indicating that the selected independent variables had a good ability to explain the dependent variable. The F-test passed the test at less than $1 \%$ significance level, indicating that the entire equation is valid. Among them, CPI and GDP passed the test at a significant

Table 1. Correlation coefficients between each factor.

\begin{tabular}{cccccc}
\hline & FDI & CPI & GDP & HLV & LLV \\
\hline FDI & 1.0000 & 0.9394 & 0.9537 & 0.1848 & -0.6517 \\
CPI & 0.9394 & 1.0000 & 0.8308 & 0.4650 & -0.7328 \\
GDP & 0.9537 & 0.8308 & 1.0000 & -0.0670 & -0.5667 \\
HLV & 0.1848 & 0.4650 & -0.0670 & 1.0000 & -0.3915 \\
LLV & -0.6517 & -0.7328 & -0.5667 & -0.3915 & 1.0000 \\
\hline
\end{tabular}

Table 2. The results of the model.

\begin{tabular}{ccccc}
\hline Variable & Coefficient & Std. Error & t-Statistic & Prob. \\
\hline GDP & 3.090326 & 1.095455 & 2.821044 & 0.0106 \\
CPI & -0.001139 & 0.000294 & 3.878246 & 0.0009 \\
HLV & 2.372373 & 23.43911 & 0.604033 & 0.9204 \\
LLV & 2.885400 & 4.776896 & 0.604033 & 0.5562 \\
C & -312.1191 & 95.24603 & -3.276977 & 0.0038 \\
\hline R-squared & & & 551.9528 \\
Adjusted R-squared & 0.979710 & Mean dependent var. & 346.1263 \\
S.E. of regression & 0.975652 & S.D. dependent var. & 10.99305 \\
Sum squared resid & 54.00949 & Akaike info criterion & 11.23683 \\
Log likelihood & 58340.49 & Schwarz criterion & 11.06067 \\
F-statistic & -132.4132 & Hannan-Quinn criterion & 1.014184 \\
Prob (F-statistic) & 241.4225 & Durbin-Watson stat & \\
\hline & 0.000000 & &
\end{tabular}


level of 5\%, while HLV and LLV failed to pass the test of significance. In order to further ensure the true and reliable results of the regression, a series of correlation tests were carried out in this paper.

3) Heteroscedasticity analysis

In this paper, the White test was used to investigate whether the error of the regression model had heteroscedasticity. The zero hypothesis of White test is that there is no Heteroscedasticity in the regression residual, and the statistic of the test is $\mathrm{Obs}^{*} \mathrm{R}$-squared. According to Table 3, the $\mathrm{P}$ value of $\mathrm{Obs}^{\star} \mathrm{R}$-squared is less than the value under a significant level of $5 \%$, which meant that the zero hypothesis unable to be rejected, that is the regression model had no Heteroscedasticity.

4) Sequence correlation analysis

In this paper, the problem of the serial correlation was analyzed by using Dubbin-Walsentest. According to the results of regression, the DW was equal to 1.0148. However when significance level is equal to $5 \%, \mathrm{~K}$ is equal to 4 , and $\mathrm{N}$ is equal to 27 , the expected value of $\mathrm{dl}$ is 1.084 , the expected value of $\mathrm{du}$ is 1.651 . Because DW is less than dl, there is a positive autocorrelation between the observed values of the sample. We corrected the dependent variable with a first-order lag, and the DW was equal to 1.1317 which still failed to achieve our expectation. Finally, we made a two order lag for FDI, and the following results were as follows in Table 4.

Table 4 shows that the modified DW $=1.759182>\mathrm{du}$, so the modified model did not have self-correlation. After modification, the new model was obtained as:

$$
\begin{aligned}
\text { FDI }= & -312.1210+4.515639 \mathrm{GDP}-0.001395 \mathrm{CPI}-14.47809 \mathrm{HLV} \\
& (-2.18) \quad(3.24) \quad(-2.92) \quad(-0.56) \\
- & 2.890658 \mathrm{LLV}+0.231359 \mathrm{FDI}(-1)-0.643560 \mathrm{FDI}(-2)
\end{aligned}
$$

Because the Adj.R2 was equal to 0.978084, the F-statistic was equal to 163.6423, the Prob (F-statistic) was equal to 0.0000 , and DW was equal to 1.7592. The fitting effect of the adjusted equation was good. The relationship between CPI and FDI was in the opposite direction, however, there was a positive correlation between GDP and FDI. With each additional unit of GDP, FDI increased 4.52 units, and each additional unit of CPI reduced the FDI by 0.0014 units. However, the effects of exchange rate HLV and interest rate LLV on FDI were not obvious in this empirical analysis.

\subsection{The Analysis of Experimental Results}

It can be seen from the experimental results that the overall fitting effect of the

Table 3. The results of white test.

\begin{tabular}{cccc}
\hline F-statistic & 3.441205 & Prob. F(9, 21) & 0.0278 \\
\hline Obs $^{\star}$ R-squared & 20.70276 & Prob. Chi-Square (9) & 0.1095 \\
Scaled explained SS & 10.08881 & Prob. Chi-Square (9) & 0.7557
\end{tabular}


Table 4. The results of the adjusted model.

\begin{tabular}{|c|c|c|c|c|}
\hline Variable & Coefficient & Std. Error & $\mathrm{t}$-Statistic & Prob. \\
\hline GDP & 4.515639 & 1.392313 & 3.243265 & 0.0051 \\
\hline CPI & -0.001395 & 0.000478 & 2.919507 & 0.0100 \\
\hline HLV & -14.47809 & 25.85316 & -0.560012 & 0.5832 \\
\hline LLV & -2.890658 & 0.249635 & 0.926791 & 0.5750 \\
\hline FDI $(-1)$ & 0.231359 & 0.243791 & -2.639807 & 0.03679 \\
\hline FDI $(-2)$ & -0.643560 & 0.243791 & -2.639807 & 0.0178 \\
\hline $\mathrm{C}$ & -312.1210 & 143.1647 & -2.180154 & 0.0445 \\
\hline R-squared & 0.984061 & \multicolumn{2}{|c|}{ Mean dependent var } & 596.9578 \\
\hline Adjusted R-squared & 0.978084 & \multicolumn{2}{|c|}{ S.D. dependent var } & 322.8400 \\
\hline S.E. of regression & 47.79291 & \multicolumn{2}{|c|}{ Akaike info criterion } & 10.81742 \\
\hline Sum squared resid & 36546.59 & \multicolumn{2}{|c|}{ Schwarz criterion } & 11.16301 \\
\hline Log likelihood & -117.4003 & \multicolumn{2}{|c|}{ Hannan-Quinn criterion } & 10.90434 \\
\hline F-statistic & 164.6423 & \multicolumn{2}{|c|}{ Durbin-Watson stat } & 1.759182 \\
\hline Prob (F-statistic) & 0.000000 & & & \\
\hline
\end{tabular}

model was good, and the fitting degree was up to 0.978084 , which showed that the framework building of the model was advisable. But we should note that, we had analyzed exchange rate and interest rate are important factors for international capital flows in the preceding section, however in this empirical analysis, the impact of interest rates and exchange rates on FDI were unable to pass the $t$ test. We reflected this phenomenon from two reasons as follows: On the one hand, model existed the multi-collinearity problem. It can be observed from the correlation coefficient matrix that there was a strong correlation between the explanatory variables of the model. On the other hand, we can see from the change trend chart of our country's interest rate that it did not change significantly for a certain time which caused the error. We require further research.

\section{References}

[1] Zhang, B.Q. (2010) The Influence of International Capital Flow on the World Economic System. Tsinghua People's Publishing House, Beijing.

[2] Li, C. and Hao, J.X. (2006) The Development and Prospect of the Theory of International Capital Flow. Journal of Xi an Jiao Tong University (Social Science), 26, 5-12.

[3] Wang, Y. (2004) Research on Capital Flow in China since 1994. International Financial Research, 6, 67-73.

[4] Wang, Q. (2006) The Construction and Analysis of the Measurement Model of the Factors Affecting the International Capital Flow in China. 2006 Forum. International Financial Research, 6, 64-69.

[5] Chen, H.P. (2008) The Effect of RMB Appreciation on China's Absorption of FDI. Time Finance, 11, 4-6. 